\title{
REFLECTIONS
}

\section{Bag of Worms}

\author{
James L. Glazer, MD
}

Department of Family Medicine and Division of Sports Medicine Maine Medical Center, Portland, Me

Conflict of interest: none reported

\section{CORRESPONDING AUTHOR}

James L. Glazer, MD

Department of Family Medicine

Maine Medical Center

272 Congress St

Portland, ME 04101

glazej@mmc.org

\section{ABSTRACT}

In this story, I describe, from my perspective as a resident, working with a surgeon to resuscitate a woman who has suffered an avulsion of her pulmonary artery. The patient, a victim of a collision with an intoxicated driver, arrived at the hospital as I was caring for another patient who was undergoing his tenth admission for detoxification. Having been thrown unexpectedly into the fray, I looked upon a beating heart for the first time

Ann Fam Med 2004;2:609-610. DOI: 10.1370/afm.140.

"P ut your hands in there. Be careful not to cup your fingers, though. Hold them out straight, like this," the surgeon told me and then demonstrated. "Squeeze gently, or else you'll puncture the myocardium." He looked me in the eye, "Have you ever done open cardiac massage before?" he asked.

I stared down in awe, shaking my head. Before me the patient's chest lay bared, the arcs of her ribs spread by the jaws of the retractor. Her pericardium, the fibrous sac covering her heart, was flayed open, and inside this gristly envelope the heart fibrillated. "Like a bag of worms," I thought, recalling the term from countless medical texts.

It had all begun for me 15 minutes earlier in the stairwell during another busy morning as a family medicine intern on the surgical service. I was minding my own business, walking upstairs to discharge Mr. Rossignol* to an alcohol rehabilitation facility when the hospital overhead pager squawked: "Respiratory to the ER STAT!" and a moment later, "Operating room crew to the ER STAT!" Clearly this was not the average emergency, so I aborted my ascent and galloped down the stairs.

The emergency department was a scene of pandemonium. A clump of personnel in baggy blue operating room scrubs spilled out of one of the rooms, revealing the site of the action. A drunk driver had struck a 28-year-old woman while she was on her way to pick up her infant from daycare. The driver of the other car was well known to us. His license had been revoked 3 times for driving under the influence. He frequented the wards of our hospital when his battered girlfriend refused to let him back inside her home. Today his luck had held ${ }_{i}$ he was not seriously injured and lay across the hall on a stretcher, bellowing at the nurses to let him go home. One of them looked over to me and nodded at the intoxicated man. "You've heard the old saying," she said, "God looks after a drunk." She paused. "Too bad He doesn't also look after mothers," she added.

The woman had been conscious when the rescue squad found her, but she went into shock while the emergency crew extracted her from her mangled car. Her neck veins bulged as an ER physician intubated her. Then the surgeon snapped on his gloves and shouldered the nurses out of the way. He glanced up at me. "Come here," he said.

We painted her chest with sterile solution as the monitor showed her

*Name changed. 
heartbeat slipping into dangerous arrhythmias and then back to normal again. Her fingers turned blue, then ashy gray, from lack of oxygen despite the anesthesiologist's efforts with the bag ventilator. "Hurry up if you want to help her," the surgeon prodded me.

I took an enormous cardiac needle from its plastic sheath, hoping that my movements would disguise the shaking of my hands. It looked impossibly long, like a prop from a Frankenstein movie. I stopped with the needle poised over her chest and looked up. The surgeon nodded to me.

The sensation of driving the needle through the layers of her chest wall was strange. The tissues seemed to adhere to the shaft as I haltingly advanced until I felt a soft pop. Suddenly the syringe blossomed with dark crimson blood. The surgeon nudged me and pointed at the monitor. While we watched, it traced the familiar pattern of a normal sinus rhythm. Relieving the pressure of the accumulated blood around the heart allowed it to beat normally again. As I moved away, I stumbled. In my tension I had been clenching my toes inside my shoes the whole time.

The patient's recovery was short-lived, and she soon slipped back into ventricular fibrillation. The cardiac needle clotted, and the surgeon called for the chest tray. With the ambulance lights flashing in our faces, the surgeon opened her chest. Using quick, confident strokes, he drew the scalpel blade over her ribs and bared the creamy yellow fat beneath the surface of her skin. Her ribs crunched as the retractor jaws clicked their way open. Inside her chest cavity the glistening gray surface of her lung bounced in and out.

The surgeon reached inside her and delivered her heart. In one sure thrust he punctured the pericardial sac. He scooped out gelatinous handfuls of clot. Soon the bowl of her chest filled with blood already thin and diluted from the fluids that were running into her veins. "We're going upstairs," he shouted over his shoulder to the waiting operating room crew, and then handed me her writhing heart. "Squeeze," he muttered.

The bright lights of the operating room failed to show the source of her bleeding. We toiled over her as the anesthesiologist littered the floor with empty bags of blood. I sucked the fluid from her chest cavity as quickly as he could infuse it into her veins, and nothing we did stemmed the flow. Finally the surgeon located a gushing, jagged stump too short to clamp-a major pulmonary artery had been torn away at its base. But by that time her heart had been fibrillating for far too long to be able to recover. Her fingertips and lips had become waxy and white. "She can not survive this injury," the surgeon sighed. "It's time to stop." The anesthesiologist nodded, and I reluctantly gave up my post at her heart. It jerked futilely for a moment and then seemed to gasp and stop. By that point even her myocardium looked pale.

I pulled off my gown, my shoes slipping on the soaked sponges piled at my feet. The surgeon extended his hand to me. It felt firm and solid, not at all like the bucking softness of the heart that I had gripped for the last hour. He thanked me for my help.

I walked from the operating room, my shoulders stooped, and my scrubs clinging to my damp back. In the stairwell I started to make my way down, toward the exit. I needed a break, some time to think about what I had just seen. I thought that books and movies had prepared me for the idea of a hospital emergency, but they offered images of infallible doctors and invulnerable patients. I knew about the white coat, but not about the bloody gloves, the stilling heart, and the motherless infant crying alone in the nursery. I was especially unprepared for the drunken man who had caused it all. I would likely be seeing him on rounds tomorrow, I thought, and again next week, and the next through countless readmissions. I might grow to know and resent him, while I would probably never learn the name of today's victim's infant daughter. The weight of it loomed over me, and I stumbled toward the wall. Then I put my thoughts away, shrugged my white coat on, and turned wearily upward, I still had to see about Mr. Rossignol's transfer to the detoxification unit. Introspection is not good medicine during the intern year.

To read or post commentaries in response to this article, see it online at http://www.annfammed.org/cgi/content/full/2/6/609.

Key words: Internship and residency; emergency medicine; substance abuse; behavioral psychological

Submitted October 22, 2003; submitted, revised, January 8, 2004; accepted January 19, 2004. 